\title{
Exopolysaccharides from Xanthomonas citri pv. malvacearum induce resistance in cotton against bacterial blight
}

\author{
Rabab A. KeshKeiH *, Mahmoud Abu-Ghorrah, Aida Jalloul \\ Department of Plant Protection, Damascus University, Damascus, Syria
}

\begin{abstract}
Xanthomonas citri pv. malvacearum $(X c m)$ is known to infect the cotton plant (Gossypium hirsutum) and causing the disease known as cotton bacterial blight. While resistant plants show a hypersensitive reaction, susceptible plants suffer from water-soaking spots before death. In this study, we attempted to control the infected susceptible Gossypium hirsutum by spraying the cotyledons with exopolysaccharides (EPS) extracted from the same virulent race of $\mathrm{Xcm}$ that infected the plants. Our studies confirmed that EPS succeeded as an elicitor in decreasing bacterial populations in the susceptible $G$. hirsutum variety ( 28 times compared to water-treated plants). Moreover, Gossypium treatment with this elicitor stimulated some defence in plants. We detected a significant increase in total peroxidase (POD) and superoxide dismutase (SOD) activities; however, no gene expression for G. hirsutum Fe-superoxide dismutase (GhFeSOD) was detected under the treatment conditions. Moreover, there was an increase in the gene expression of lipoxygenase (GhLOX1). In conclusion, in this study, we observed an increase in expression of the GhLOX1 gene, decrease in bacterial populations and a stimulation of POD activity after EPS treatment. The results confirmed that EPS treatment may stimulate certain defence responses against $X c m$ in susceptible Gossypium hirsutum plants.
\end{abstract}

Key words: exopolysaccharides, cotton, Gossypium hirsutum, Induce Resistance, Xcm

\section{Introduction}

Cotton bacterial blight (CBB), which is caused by Xanthomonas citri pv. malvacearum $(X \mathrm{~cm})$, can spread to all cotton-growing areas around the world. It is a serious and potentially destructive disease that can seriously limit cotton production (Bayles and Verhalen, 2007). In Syria, the rate and severity of infections by $\mathrm{CBB}$ under spring irrigation were significantly greater than when flood irrigation was used. In 2010, CBB caused $>30 \%$ damage in certain localities (Jalloul et al., 2015). Recent field surveys have revealed the occurrence of genetic diversity among Syrian $\mathrm{Xcm}$ isolates, which is currently under molecular investigation. Although Syrian cotton cultivars are of high quality and have a high yield under different agroclimatic conditions, they are very susceptible to CBB (Jalloul et al., 2015). The control of this disease using disease-resistant cultivars with one or two major resistance genes ( $R$ genes) is unsustainable because of the high pathogenic variability of Xcm (Fallahzadeh et al., 2010). Moreover, no single $R$ gene confers durable resistance or immunity to $\mathrm{CBB}$ because of the evolutionary shifts in $\mathrm{Xcm}$ virulence in response to selection pressures imposed by the resistant varieties (Jalloul et al., 2015). Currently, stimulating induced systemic resistance (ISR), classified as a type of induced resistance to plants, is considered an environmentally friendly strategy as agents that are known to be eco-friendly are used with a promising future for controlling plant diseases. As reported, ISR was triggered either via beneficial soil-borne microorganisms such as mycorrhizal fungi and plant growth-promoting rhizobacteria (Fallahzadeh and Ahmadzadeh, 2010; Pozo and Azcon-Aguilar, 2007) or by materials such as Flagellin from many bacteria (Felix et al., 1999), or siderophores from Pseudomonas (Fallahzadeh et al., 2009) or bacterial exopolysaccharides (EPSs) (Griesbach et al.,

\footnotetext{
* Corresponding author: Department of Plant Protection, Damascus University, Damascus, Syria; e-mail: rabab.keshkeih@gmail.com
} 
2000). These biopolymers are primarily secreted by bacterial cells to anchor them to surfaces of leaves and to modify the environment around the cells to one that is more favourable for growth and survival (Beattie and Lindow, 1999). This happens under the control of quorum sensing (QS) by regulating gene expression for proteins involved in the biosynthesis of EPS (Ciszek-Lenda, 2011). Moreover, plants are genetically prepared to sense microbial molecular signatures, called microbeassociated molecular patterns (MAMPs), thus activating an immune response (Zhang and Zhou, 2010). In Xanthomonas species, EPSs, which are considered MAMPs molecules, act as pathogenicity factors because of their role in the initial colonisation and development of disease symptoms (Guzzo et al., 1993; Denny, 1995). Different EPSs possess different abilities that affect plant metabolism because the alteration of biochemical pathways involved in plant responses against pathogens are induced by many but not all the EPSs that were used (de Pinto et al., 2003). However, EPSs can be recognised via plants and triggers different responses of defence. Moreover, the bioprocess involved for obtaining them is generally cheap and generates a low environmental impact. Thus, the use of a microbiological approach to induce resistance in plants has a strong technological appeal and high commercial potential because of the possibility of an accurate control of the production process, resulting in stable, standardised and high-quality raw materials that are easily extracted and can bring environmental advantages (Huang and Mcdonald, 2009; Baque et al., 2012). Moreover, these bacterial molecules have multiple applications in many fields such as food, the pharmaceutical industry, chromatographic media, cosmetics, heavy metal removal, oil recovery and the petroleum industry (Nwodo et al., 2012). For example, EPSs from marine bacteria possess antibacterial activity against gram-positive and gram-negative bacteria (Orsod et al., 2012). However, the biological functions of EPSs and their properties are affected by several factors such as the composition and molecular structure of EPS, the type of microorganism and the environmental conditions (Freitas et al., 2011).

In the past 35 years, a lot of data has been generated on how Gossypium modulates its defence strategy toward $\mathrm{Xcm}$. This resistance of Gossypium to CBB is based on the gene-for-gene concept, which assumes that pathogenic avirulence and plant resistance only occurs if the pathogen possesses an avirulence gene (avr gene) for which a corresponding $R$ gene exists in the host plant (Flor, 1971). The Xcm-Gossypium interactions corresponded to the gene-for-gene model of host plant resistance (Delannoy et al., 2005, Jalloul et al., 2015), indicating the existence of a specific molecular dialogue between the paired plant-bacterial gene participants. This resistance is characterised by a rapid, localised cell death at the infectious sites, which is known as the hypersensitive response (HR) that spreads throughout the whole plant as systemic acquired resistance (SAR). $\mathrm{HR}$ is associated with the oxidative burst, which produces reactive oxygen species (ROS) in a range of physiological events during the plant's life. In Gossypium, ROS are known to be produced during fibre elongation (Mei et al., 2009). For HR-like resistance, the burst is considered a key event, which was investigated during the Gossypium hirsutum defence to $\mathrm{Xcm}$ with a peak in $3 \mathrm{hpi}$. This behaviour increases the activity of scavenger enzymes such as peroxidase (POD) and superoxide dismutase (SOD) (Martinez et al., 1996; Voloudakis et al., 2006), the accumulation of salicylic acid (Martinez et al., 2000 ), the mass production of polyunsaturated fatty acid (PUFA) hydroperoxides with typical tissue dehydration mediated by 9S-LOX activity (Jalloul et al., 2002) and an association with patatin-like activation (Cacas et al., 2009). These events are considered as markers for Gossypium resistance response toward $\mathrm{Xcm}$.

In this study, we used EPS from the virulent $X \mathrm{~cm}$ race to induce the resistance of susceptible Syrian $\mathrm{Gos}^{-}$ sypium hirsutumvarieties (Aleppo33/1 and Aleppo 118), which produce a high quality and quantity of Gossypium hirsutum and tolerate the verticillium disease against $X \mathrm{~cm}$ by the EPS of $X \mathrm{~cm}$. The final aim was to develop a method for controlling this bacterial disease.

\section{Materials and methods}

\section{Plant Growth and treatment}

In this study, we used Gossypium hirsutum Aleppo 118 cultivar susceptible to $\mathrm{Xcm}$. We planted 13 chemical delinting seeds in pots containing 11 of tourbe (KEKKILA garden). The pots were placed under greenhouse conditions $\left(16 / 8 \mathrm{~h}\right.$ light/dark cycle at $30 / 25^{\circ} \mathrm{C}$ with $80 \%$ relative humidity), which have been shown to favour bacterial development. Twenty day-old cotyledons were sprayed with EPS (10 g/l) of $\mathrm{Xcm}$ using water as a control. Four replicates for every experiment were prepared. 


\section{Bacterial strain and growth condition}

In this experiment, the Syrian isolate $X c m 101$ used was collected from naturally infected seeds of the cultivar Aleppo 33/1. Bacterial growth was obtained at $30^{\circ} \mathrm{C}$ on YPGA medium $(0.7 \% \mathrm{w} / \mathrm{v}$ yeast extract, $0.7 \% \mathrm{w} / \mathrm{v}$ bacteriological peptone and $0.7 \% \mathrm{w} / \mathrm{v}$ glucose as a carbon source, solidified with $1.5 \% \mathrm{w} / \mathrm{v}$ agar) supplemented with cycloheximide $(50 \mathrm{mg} / \mathrm{l})$ as a fungicide.

\section{Preparation of bacterial suspensions}

$X \mathrm{~cm}$ suspension was prepared using a $24 \mathrm{~h}$-old bacterial culture that was collected and washed twice with sterile water and centrifuged at $5000 \mathrm{~g}$ for $5 \mathrm{~min}$ to remove nutrients and exopolysaccharides. The bacterial pellet was re-suspended in sterile water and adjusted to $10^{8}$ colony forming units $/ \mathrm{ml}(\mathrm{CFU} / \mathrm{ml})$. The bacterial suspension was injected into intercellular areas of the cotyledon leaf parenchyma of 20 day-old plants using a syringe without a needle.

\section{Bacterial growth determination}

In the plant tissues, the bacterial growth was evaluated using the plate count technique as described by Marmey et al. (2007) for 0, 1, 2, 3, 6, 8 and 10 days postinoculation (dpi). Four discs (diameter $=7 \mathrm{~mm}$ ) of inoculated cotyledons were collected using a brass cork borer, ground up in $3 \mathrm{ml}$ of sterile, deionised water. The suspension was serially diluted $\left(10^{-3}, 10^{-4}, 10^{-5}\right.$ and $10^{-6}$ ) in sterile water, and $10 \mu \mathrm{l}$ of each dilution was plated on YPGA at $30^{\circ} \mathrm{C}$. Then, the bacterial concentration for the infected cotyledons was calculated and expressed as $\log _{10} \mathrm{CFU} / \mathrm{cm}^{2}$ tissue. Note that the experiment was replicated three times.

\section{Cotyledon excision experiments}

To determine the effect of EPS or $\mathrm{H}_{2} \mathrm{O}$ as controls on the trigger SAR, treated cotyledons $(1 \mathrm{~g})$ were excised or collected from plants at $1,5,23,29,48,52,73,95$ and $99 \mathrm{~h}$ post-treatment (hpt). Enzymatic activity was measured using frozen cotyledons $\left(-80^{\circ} \mathrm{C}\right)$. Moreover, four replicates for each time point were performed.

\section{Total protein extraction and enzyme assays}

Gossypium hirsutum extracts were prepared according to the procedure described by Martinez et al. (2000) in which $1 \mathrm{~g}$ of frozen cotyledon tissues and Tris$\mathrm{HCl}$ buffer $(\mathrm{pH}=7)$ containing basic Tris $(50 \mathrm{mM}), \mathrm{NaCl}$
(50 $\mathrm{mM}), \beta$-mercapto-ethanol (5 mM), PVP (1\%) and Triton $100 \mathrm{X}(0.01 \%)$. The plant crude extract was centrifuged at $16,000 \mathrm{~g}$ for $15 \mathrm{~min}$ at $4^{\circ} \mathrm{C}$, which was then used for POD and SOD activities. The fresh extract was used for spectrophotometric assay, while the frozen extract with glycerol (10\%) was used in vertical native polyacrylamide gel electrophoresis (PAGE; $4 \%$ for a concentration gel and $10 \%$ for separation). We determined the presence of proteins using Bradford (1976)'s method with bovine serum albumin (BSA; Sigma) as a standard. Equal amounts of total protein (25 g for each sample) were run on native $10 \%$ acrylamide/bisacrylamide gels (Laemmli et al., 1970) for $4 \mathrm{~h}$ at $200 \mathrm{~V}$ at $4{ }^{\circ} \mathrm{C}$ (Delannoy et al., 2003). Note that the experiments were replicated three times.

The POD activity for the native polyacrylamide gel (10\%) was determined using $10 \%$ dimethylformamide (DMF), 0.2\% guaiacol, 0.01\% 3-amino-9-ethylcarbazole, and $0.03 \% \mathrm{H}_{2} \mathrm{O}_{2}$ in a sodium phosphate buffer $\left(\mathrm{KH}_{2} \mathrm{PO}_{4} /\right.$ $\left.\mathrm{K}_{2} \mathrm{HPO}_{4}\right)(50 \mathrm{mM} ; \mathrm{pH} 6)$. The gels were incubated in this mixture for $15 \mathrm{~min}$ at room temperature until (the) colour appeared, while the POD activity was spectrophotometrically assessed at $470 \mathrm{~nm}$, using $0.01 \%$ guaiacol (Sigma) as a hydrogen donor with $0.03 \% \mathrm{H}_{2} \mathrm{O}_{2}$. The molar extinction coefficient of tetraguaiacol is $26.6 \times$ $10^{3} \mathrm{M}^{-1} \mathrm{~cm}^{-1}$. Total activity was expressed in nanoKatals per mg of proteins (Martinez et al., 2000).

The SOD activity for the native polyacrylamide gel was identified/determined by negative staining in the sodium phosphate buffer (50 mM, pH 7.5-7.8) using riboflavin $(25 \mathrm{mg})$ and TEMED $(10 \mu \mathrm{l})$ as anion superoxide generators under light with nitro blue tetrazolium (NBT; $25 \mathrm{mg}$ ) as an anion superoxide acceptor (Voloudakis et al., 2006). The gel was incubated for $30 \mathrm{~min}$ in the dark at room temperature, after which the gel was washed with sodium phosphate buffer and exposed to natural light. Note that the competition between SOD and NBT for anion superoxide permits the localisation of transparent SOD bands on the background gel in dark blue (which appears because of Formazan formation).

\section{Nucleic acid extraction and reverse transcriptase polymerase chain reaction (RT-PCR)}

DNA and total RNA were extracted from frozen 21 day-old cotyledons of treated plants using the Wizard Genomic DNA purification kit (Promega, USA) and RNasy Plant Mini Kit (Qiagen, France), respectively, 
Table 1. Oligonucleotide sequence used in PCR reation

\begin{tabular}{c|l|c|c}
\hline \multirow{2}{*}{ Primer set } & \multicolumn{1}{c|}{ Sequence } & \multicolumn{2}{c}{ Size [bp] } \\
\cline { 3 - 4 } GhFe-SOD & $\begin{array}{l}\text { For 5'-CATTGGGGAAAGCATCATC-3' } \\
\text { Rev 5'-GTCCAGATAATAAGAGT- 3' }\end{array}$ & DNA \\
\hline GhLOX1 & $\begin{array}{l}\text { For 5'-GCATGGAGGACTGATGAAGAGTT-3' } \\
\text { Rev 5'-GCATGGAGGGCTGAAGCTATCCAGAT-3' }\end{array}$ & 1062 & 1463 \\
\hline GhActin & $\begin{array}{l}\text { L 5'-ATTGTGAGCAACTGGGATGA-3' } \\
\text { R 5'-GTAGATGGGGACGGTGTGAG-3' }\end{array}$ & 276 & 376 \\
\hline
\end{tabular}

Table 2. PCR programs

\begin{tabular}{|c|c|c|c|c|c|c|c|}
\hline & \multicolumn{2}{|c|}{ GhFe-SOD } & \multicolumn{2}{|c|}{ GhLOX1 } & \multicolumn{2}{|c|}{ GhActin } \\
\hline & & $\begin{array}{c}\text { temperature } \\
{\left[{ }^{\circ} \mathrm{C}\right]} \\
\end{array}$ & $\begin{array}{l}\text { time } \\
{[\mathrm{min}]}\end{array}$ & $\begin{array}{c}\text { temperature } \\
{\left[{ }^{\circ} \mathrm{C}\right]} \\
\end{array}$ & $\begin{array}{l}\text { time } \\
{[\mathrm{min}]}\end{array}$ & $\begin{array}{c}\text { temperature } \\
{\left[{ }^{\circ} \mathrm{C}\right]} \\
\end{array}$ & $\begin{array}{c}\text { time } \\
{[\mathrm{min}]}\end{array}$ \\
\hline Initial denaturation & & 94 & 3 & 94 & 3 & 94 & 3 \\
\hline Denaturation & \multirow{3}{*}{$\begin{array}{c}40 \\
\text { cycles }\end{array}$} & 94 & 1 & 94 & 1 & 94 & 1 \\
\hline Annealing & & 52 & 1 & 54 & 1 & 55 & $30 \mathrm{~s}$ \\
\hline Extension & & 72 & 1 & 72 & 2 & 72 & $30 \mathrm{~s}$ \\
\hline Final extension & & 72 & 10 & 72 & 10 & 72 & 10 \\
\hline
\end{tabular}

based on the manufacturers' instructions. RNA ( $1 \mathrm{~g})$ was reverse-transcribed with the RevertAid First Strand cDNA Synthesis Kit (Thermoscientific, Canada) using oligo- $\left(\mathrm{dT}_{18}\right)$ as a primer, as described by the manufacturer. For PCR reactions, a pair of primers for GhFe-SOD, GhLOX1, and GhActin (Table 1) is used. The PCR reaction mixture $(50 \mu \mathrm{l})$ contained the PCR GoTaq polymerase mixture (Promega, USA), $30 \mathrm{pmol}$ of each primer, and $50 \mathrm{ng}$ of each $\mathrm{RT}$ reaction. We performed the amplification as described in Table 2 .

\section{Statistics}

Sample variability for $\mathrm{n} \geq 3$ was given as the standard error of the mean. All enzyme assays were performed at least in duplicate. The significance of differences was determined using $P$-values where $P \leq 0.05$ was considered significant. We used both Microsoft Office Excel (2007) and SPSS to analyse the data.

\section{Results}

\section{The effect of exopolysaccharides on the Xcm population}

The bacterial population started to decrease on the $3^{\text {rd }}$ day post inoculation (pi) with $X c m$ (Fig. 1). On the $6^{\text {th }}$ dpi, the bacterial population was 18.6 times lower for

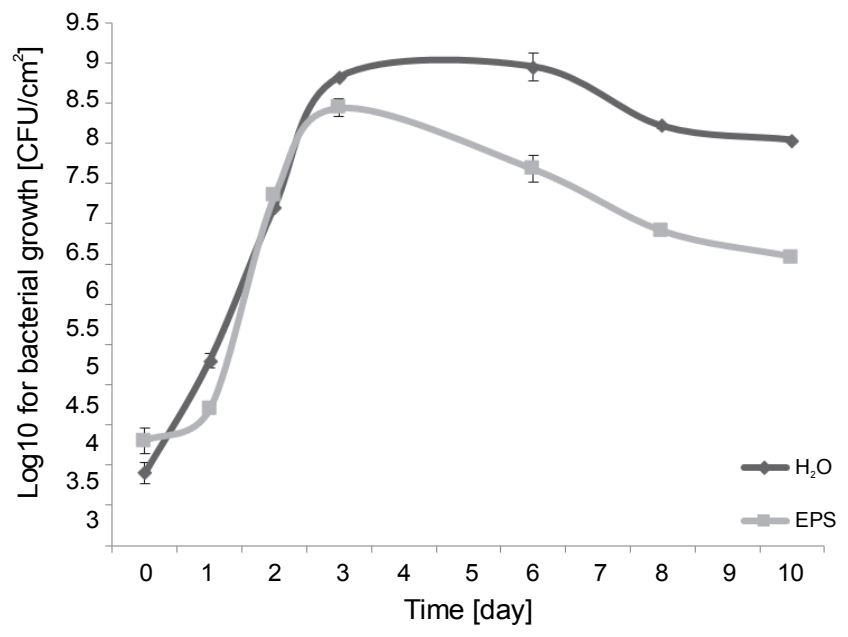

Fig. 1. Effect of EPS (10 g/l) spraying cotyledons on $\mathrm{Xcm}$ development

EPS-treated cotyledons than that in controls $(7.68 \pm$ $0.11 \mathrm{CFU} / \mathrm{Cm}^{2}$ for EPS-treated and $8.95 \pm 0.01 \mathrm{CFU} / \mathrm{Cm}^{2}$ for $\mathrm{H}_{2} \mathrm{O}$-treated cotyledons). This difference in the bacterial population between EPS-treated cotyledons and controls continued with time; it was about 20 and 28 times lower than the control on the $8^{\text {th }}$ and $10^{\text {th }}$ dpi with $X \mathrm{~cm}$, respectively. The difference between the two means of EPS-treated plants and the control over time was significant with $P$-values $<0.05$ (Table 3 and Table 4). 
Table 3. One sample statistics to effect of EPS (10 g/l) spraying cotyledons on $\mathrm{Xcm}$ development experiment

\begin{tabular}{c|c|c|c|c}
\hline \multicolumn{5}{c}{ One Sample Statistics } \\
\hline & $N$ & mean & standard deviation & standard error mean \\
\hline EPS & 7 & 6.5643 & 1.53433 & 0.57992 \\
\hline $\mathrm{H}_{2} \mathrm{O}$ & 7 & 7.2043 & 1.91105 & 0.72231 \\
\hline
\end{tabular}

Table 4. One sample test to effect of EPS (10 g/l) spraying cotyledons on $\mathrm{Xcm}$ development experiment

\begin{tabular}{c|c|c|c|c|c|c}
\hline \multicolumn{7}{c}{ One Sample Test } \\
\hline & \multicolumn{7}{c}{ test value $=0$} \\
\hline & $t$ & $d f$ & significance (2-tailed) & mean difference & $\begin{array}{c}\text { 95\% confidence interval } \\
\text { of the difference }\end{array}$ \\
\hline EPS & 11.319 & 6 & 0.000 & 6.56429 & 5.1453 & upper \\
\hline $\mathrm{H}_{2} \mathrm{O}$ & 9.974 & 6 & 0.000 & 7.20429 & 5.4369 & 8.9717 \\
\hline
\end{tabular}

\section{Exopolysaccharides inducing resistance}

According to previous results (Fig. 1), which demonstrated that EPS can decrease bacterial populations in Gossypium hirsutum plants sprayed with EPS, and to determine the role of EPS in induction resistance responses, we studied the markers of Gossypium hirsutum resistance by evaluating peroxidase and superoxide dismutase activity along with lipoxygenase expression.

\section{Evaluation of Peroxidase Activity}

The POD activity was spectrophotometrically detected for $99 \mathrm{~h}$ in crude extracts of EPS-treated and water-treated cotyledons (Fig. 2). EPS-treated cotyledons had a strong POD activity for $50 \mathrm{~h}$; the activity peak was at $29 \mathrm{~h}$, compared to the control. The difference between the two means of the EPS-treated plants and the control over time was significant with a $P$-value $<0.05$ (Table 5 and Table 6 ). These results were confirmed on the native polyacrylamide gel stained with both guaiacol and 3-amino-9-ethylcarbazole (Fig. 3); moreover, an increase in the staining intensity was observed in the EPS-treated cotyledons compared to water-treated cotyledons. A higher staining intensity was observed from $5 \mathrm{~h}$ to $48 \mathrm{~h}$ post treatment with EPS compared to the control.

\section{Evaluation of superoxide dismutase activity expression}

Gels stained with NBT showed multiple bands of enzymes with different molecular weights, represented

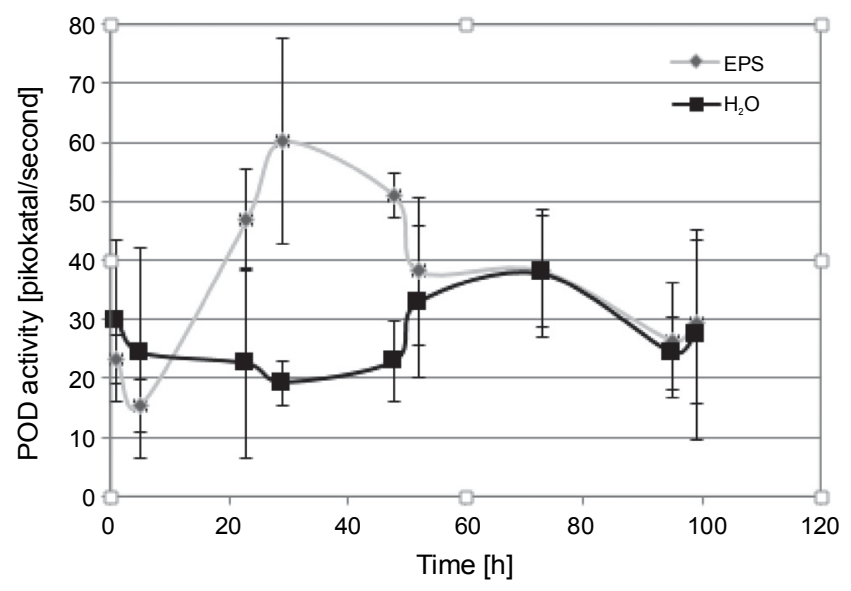

Fig. 2. Evaluations of total peroxidase activity in $\operatorname{EPS~}(10 \mathrm{~g} / \mathrm{l})$ spraying cotyledons

as six bands (Fig. 4). In EPS-treated cotyledons, the total SOD activity increased at $1 \mathrm{~h}, 52 \mathrm{~h}$ and $73 \mathrm{~h} \mathrm{pt}$, whereas it decreased at $29 \mathrm{~h}, 95 \mathrm{~h}$ and $99 \mathrm{~h}$ pt compared to water-treated cotyledons. Furthermore, band A had a strong activity in the first two days pt (until 52h), which was lower in 95-99 h pt in EPS-treated cotyledons compared to the control. However, bands F, G, H and I showed no significant change in the total SOD activity for both EPS-treated cotyledons and controls. The different bands that appeared on polyacrylamide gels represent different isoenzymes of SOD. Unfortunately, the quality of gel images was poor and did not allow us to deterimne which isoenzyme was increasing in response to the treatment of Gossypium hirsutum with 
Table 5. One sample statistics to evaluation of total peroxidase activity in EPS (10 g/l) spraying cotyledons experiment

\begin{tabular}{c|c|c|c|c}
\hline \multicolumn{5}{c}{ One Sample Statistics } \\
\hline & $N$ & mean & standard deviation & standard error mean \\
\hline EPS & 9 & 36.544 & 14.3947 & 4.7982 \\
\hline $\mathrm{H}_{2} \mathrm{O}$ & 9 & 26.756 & 5.8226 & 1.9409 \\
\hline
\end{tabular}

Table 6. One sample test to evaluation of total peroxidase activity in EPS (10 g/l) spraying cotyledons experiment

\begin{tabular}{c|c|c|c|c|c|c}
\hline \multicolumn{7}{c}{ One Sample Test } \\
\hline & \multicolumn{6}{c}{ test value $=0$} \\
\hline & $t$ & $d f$ & significance (2-tailed) & mean difference & $\begin{array}{c}\text { lower } \\
\text { of the difference }\end{array}$ & upper \\
\hline EPS & 7.616 & 8 & 0.000 & 36.5444 & 25.480 & 47.609 \\
\hline $\mathrm{H}_{2} \mathrm{O}$ & 13.785 & 8 & 0.000 & 26.7556 & 22.280 & 31.231 \\
\hline
\end{tabular}

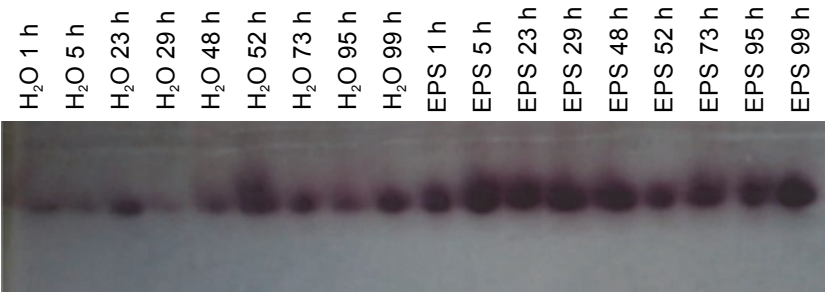

Fig. 3. Staining intensity of POD activity on native polyacrylamide gel in EPS $(10 \mathrm{~g} / \mathrm{l})$ spraying cotyledons

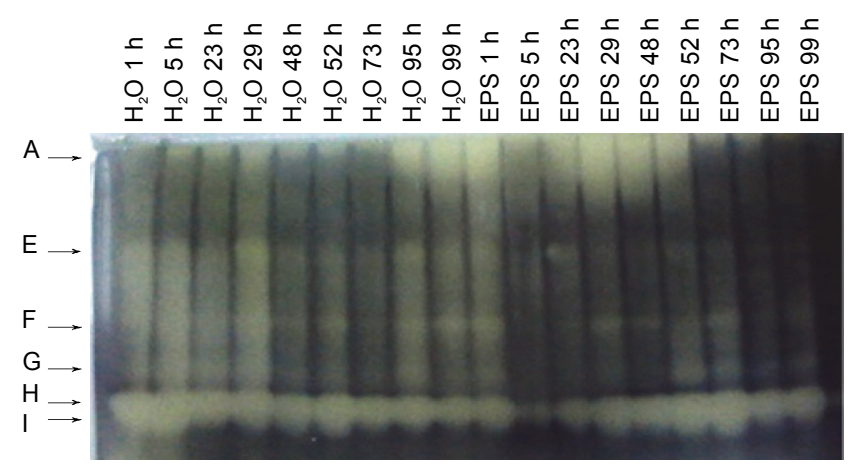

Fig. 4. Staining intensity of SOD activity on native polyacrylamide gel in EPS $(10 \mathrm{~g} / \mathrm{l})$ spraying cotyledons

different elicitors. However, there was a clear difference in total SOD activity between the treated Gossypium hirsutum and the controls.

\section{Expression of the GhLOX1 and GhFeSOD gene post-EPS treatment}

RNA from cotyledons at various times post-treatment was extracted and transformed to cDNA to detect the
GhLOX1 expression, which was a marker of Gossypium hirsutum resistance toward $X \mathrm{~cm}$, by the electrophoresis of PCR products. In EPS-sprayed cotyledons $23 \mathrm{~h} \mathrm{pt,}$ GhLOX1 expression was increased compared to watertreated cotyledons. However, the expression decreased at $48 \mathrm{~h}$ post treatment for EPS-treated cotyledons compared to water-treated ones. We did not detect any significant change in GhLOX1 expression at $5 \mathrm{~h}$ and $29 \mathrm{~h}$ post-treatment (Fig. 5A). However, the results obtained from the electrophoresis on an agarose gel demonstrated that there was no expression of the GhFeSOD gene post-EPS Gossypium hirsutum treatment in experimental conditions (Fig. 5B and Fig. 5C).

\section{Discussion}

Our results confirmed that EPS succeeded in decreasing the bacterial population in cotyledons. However, in the first three days post-inoculation of $\mathrm{Xcm}$, the bacterial population increased in both treated and untreated plants until a suitable threshold was reached. This $X \mathrm{~cm}$ growth may be because of the absence of molecules secreted by bacteria at certain CFUs, i.e., the EPS capacity to control the bacterial blight of Gossypium hirsutum may be related to the plant's ability to recognise molecules from microorganisms (MAMPs). This recognition is known to occur by the receptors located on the cell membrane surface or inside the cell, which triggers a signal transduction cascade and leads to 


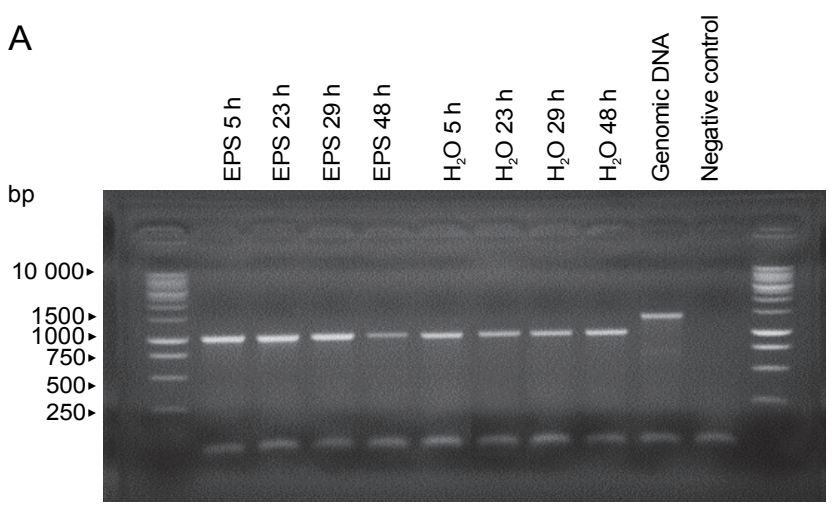

B

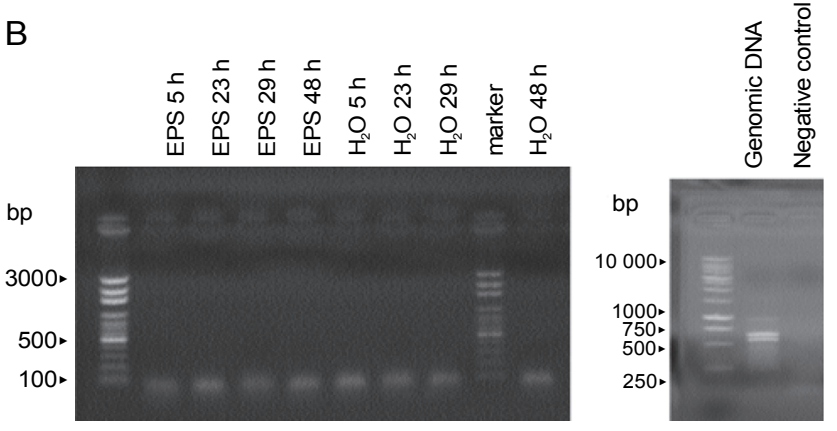

C

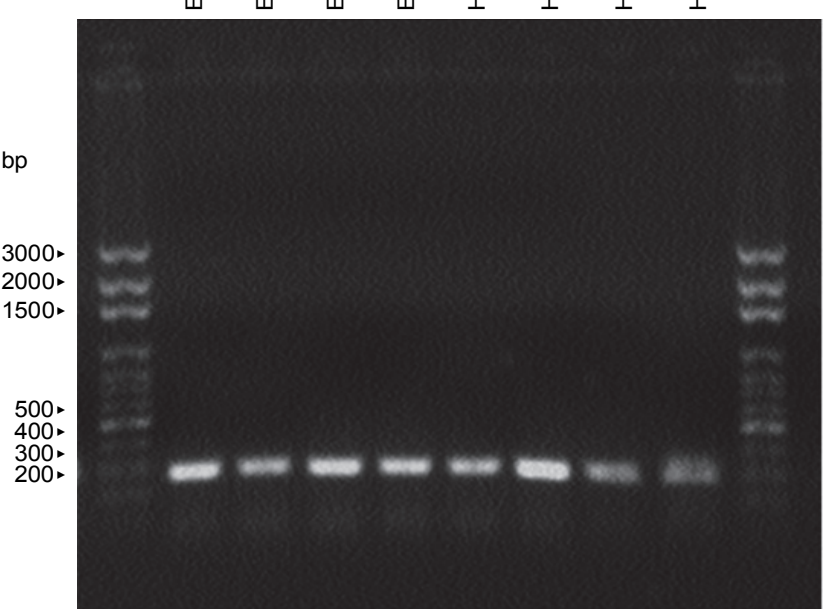

Fig. 5. Expression analysis of GhLOX1 and GhFeSOD. A) RTPCR expression profiles of GhLOX1 in EPS (10 g/l) spraying cotyledons, water used as a control; B) RT-PCR expression profiles of GhFeSOD in EPS ( $10 \mathrm{~g} / \mathrm{l})$ sprayed cotyledons water used as a control; C) actin was amplified as an internal control (Jalloul et al., 2002)

the activation of defence mechanisms. This type of defence allows plants to quickly and efficiently respond to several pathogens (Shang et al., 2007; Zhang and Zhou, 2010; Rutherford and Bassler, 2012). Many previous studies focused on the use of EPSs to induce plant resistance. Blainski et al., (2017) demonstrated that Lactobacillus plantarum EPS reduced the severity of tomato bacterial spot, while Antoniazzi et al., (2008) observed that bacterial EPSs reduced the disease severity caused by Bipolaris sorokiniana in tomato plants by $75 \%$. Moreover, these effects were observed in studies with tomato plants against $X$. gardneri (Luiz et al., 2015) and in studies with EPS extracted from $X$. campestris, which induced resistance in wheat plants against Bipolaris bicolor, Bipolaris sorokiniana, and Drechslera tritici-repentis (Bach, 1997; Bach et al., 2003). However, certain previous studies used EPS from non-pathogenic bacteria to stimulate defence plant responses and induce resistance against pathogens (de Pinto et al., 2003; Kyungseok et al., 2008). Furthermore, another study used EPS isolated from an avirulent strain to protect plants against challenge infection by virulent strains (Griesbach et al., 2000). Thus, infiltrating Arabidopsis or Nicotina with xanthan, purified from $X c c$, suppressed callose deposition in the plant cell wall (Yun et al., 2006). Milling and co-workers (2011) suggested that purified EPS triggered significant SA pathway defence gene expression in resistant but not susceptible tomato plants, whereas another study demonstrated that EPS triggered the jasmonic acid pathway in tomato plants (Blainski et al., 2017). JA is a phytohormone that is directly involved in the plant defence responses against stress and is used as a stress indicator. Indeed, the involvement of EPS from bacteria for reducing disease symptoms has not been determined to date (Kyungseok et al., 2008). Vigna radiate seed treatment with microbial polysaccharides (solution of both xanthan and gellan gums) stimulated phenolic content, enzyme activity (glucose-6-phosphate dehydrogenase and guaiacol peroxidase), antioxidant activity, as well as occasional cotyledon pigmentation (McCue and Shetty, 2002). In this study, the activation of defence mechanisms has been achieved by changes in the POD activity, which constituted an important part of the ROS homeostasis of plants treated with EPS. However, the data related to the SOD activity led us to propose that in the tetraploid Gossypium hirsutum genome, other $\mathrm{GhFeSOD}$ or $\mathrm{Mn}-\mathrm{Cu} / Z n S O D$ genes maybe expressed. Our results and those of other studies indicated that, during biotic (Voloudakis et al., 2006) and abiotic stress (Meloni et al., 2003), there is inhibition or activation of SOD enzymes in Gossypium hirsutum plants. However, Voloudakis and co-workers (2006) indicated that the $G h F e S O D$ gene is expressed during incompatible interactions between Gossypium and $\mathrm{Xcm}$. 
This led us to propose that the activation of SOD after Gossypium hirsutum treatment was because of the expression of other genes and that the gene that was tested may only be related to incompatible interactions.

The application of EPS in Gossypium hirsutum plants triggered an increase in the LOX activity. Similar results were reported by Blainski et al., (2017) who detected a high LOX activity in tomato plants when treating Lactobacillus plantarum with EPS against Xanthomonas gardneri. In a previous study, the injection of Gossypium hirsutum cotyledons with different concentrations of SA was reported to have a significant effect on increasing the LOX activity and GhLOX1 expression during the first $24 \mathrm{~h}$ post-infiltration (Marmey et al., 2007). Similarly, Gossypium hirsutum seeds treated with chitosan or SA have strong POD as well as LOX activities and clearly decreasing bacterial population in crude Gossypium hirsutum plants (Keshkeih et al., unpublished data).

\section{Conclusions}

Our results indicate that the EPS of $X \mathrm{~cm}$ was able to decrease the severity of bacterial blight in cotton by preconditioning the plant and increasing the compounds and enzymes related to the plant defence from different plant defence pathways.

\section{Acknowledgement}

We thank Ruba Naman for supporting the study with EPS, which was extracted as part of her Master's degree.

\section{References}

Bach E.E. (1997) Morphological distinction and isozyme of Bipolaris spp. and Drechslera tritici-repentis in wheat: Biochemical aspects in the interactions and resistance induction. Dissertation, University of Sao Paulo.

Bach E.E., Barros B.C., Kimati H. (2003) Induced resistance against Bipolaris bicolor, Bipolaris sorokiniana and Drechslera tritici-repentis in wheat leaves by xantham gum and heat-inactivate conidia suspension. J. Phytopathol. 151: 411-418.

Baque M.A., Mho S.H., Lee E.J., Zhong J.J., Paek K.Y. (2012) Production of biomass and useful compounds from adventitious roots of high-value added medicinal plants using bioreactor. Biotechnol. Adv. 30: 1255-1267.

Bayles M.B., Verhalen L.M. (2007) Bacterial blight reactions of sixty-one upland cotton cultivars. J. Cotton Sci. 11: 40-51.

Beattie A., Lindow S. (1999) Bacterial colonization of leaves: a spectrum of strategies. Am. Phytopathol. Soc. 89: 353-359.

Blainski J.M.L., da Rocha Neto A.C., Luiz C., Rossi M.J., Di Piero R.M. (2017) Lactobacillus plantarum exopolysaccha- rides induce resistance against tomato bacterial spot. J. Agric. Sci. 9(2): 162.

Bradford M. (1976) A rapid and sensitive method for quantitation of microgram quantities of protein utilizing the principle of protein-dye binding. Anal. Biochem. 72: 248-254.

Cacas J., Marmey Ph., Montillet L., Sayegh-Alhamdia M., Jalloul A., Rojas-Mendoza A., Clérivet A., Nicole M. (2009) A novel patatin-like protein from cotton plant, GhPat1, is coexpressed with GhLox1 during Xanthomonas campestrismediated hypersensitive cell death. Plant Cell Rep. 28: 155-164.

Ciszek-Lenda M. (2011) Biological functions of exopolysaccharides from probiotic bacteria. Centr. Eur. J. Immunol. 36: 51-55.

De Pinto M., Lavermicocca P., Evidente A., Corsaro M., Lazzaroni S., Gara L. (2003) Exopolysaccharides produced by plant pathogenic bacteria affect ascorbate metabolism in Nicotiana tabacum. Plant Cell Physiol. 44: 803-810.

Delannoy E., Jalloul A., Assigbetsé K., Marmey P., Geiger J.P., Lherminier J.F., Daniel J.F., Martinez C., Nicole M. (2003) Activity of class III peroxidases in the defense of cotton to bacterial blight.Mol.Plant Microbe Interact. 16: 1030-1038.

Delannoy E., Lyon B., Marmey P., Jalloul A., Daniel J., Montillet J., Essenberg M., Nicole M. (2005) Resistance of cotton towards Xanthomonas campestris pv. malvacearum. Ann. Rev. Phytopathol. 43: 63-82.

Denny T. (1995) Involvement of bacterial polysaccharides in plant pathogenesis. Ann. Rev. Phytopathol. 33: 173-197.

Fallahzadeh V., Ahmadzadeh M., Marefat A., Ghazanfary K. (2009) Application of rhizobacteria for induction of systemic resistance to bacterial blight of cotton caused by Xanthomonas campestris pv. malvacearum using fluorescent pseudomonas of rhizosphere. J. Plant Prot. Res. 49: 416-420.

Fallahzadeh V., Ahmadzadeh M. (2010) Induction of systemic resistance to bacterial blight caused by Xanthomonas axonopodis $p v$. malvacearum in cotton by fluorescent pseudomonads of cotton rhizosphere. J. Agric. Tech. 6: 341-348.

Felix G., Duran J., Volko S., Boller T. (1999) Plants have a sensitive perception system for the most conserved domain of bacterial flagellin. Plant J. 18: 265-276.

Flor H.H. (1971) Current status of the gene-for-gene concept. Ann. Rev. Phytopathol. 9: 275-296.

Freitas F., Alves V.D., Reis M.A. (2011) Advances in bacterial exopolysaccharides: from production to biotechnological applications. Trends Biotechnol. 29(8): 388-398.

Griesbach E., Eisbein K., Sotirova V. (2000) Induction of resistance to Clavibacter michiganensis subsp. michiganensis. Acta Physiol. Plant. 22: 359-362.

Huang T.K., Mcdonald K.A. (2009) Bioreactor engineering for recombinant protein production in plant cell suspension cultures. Biochem. Eng. J. 45: 168-184.

Jalloul A., Montillet J., Assigbetsé K., Agnel J., Delannoy E., Daniel J., Marmey P., Geiger J., Nicole M. (2002) Lipid peroxidation in cotton-Xanthomonas interactions. Role of lipoxygenases during the hypersensitive reaction and leaf blight. Plant J. 32: 1-12. 
Jalloul A., Sayegh M., Champion A., Nicole M. (2015) Bacterial blight of cotton. Phytopathol. Mediter. 54(1): 3-20.

Kyungseok P., Kloepper J., Ryu Ch. (2008) Rhizobacterial exopolysaccharides elicit induced resistance on cucumber. J. Microbiol. Biotechnol. 18: 1095-1100.

Laemmli U. (1970) Cleavage of structural proteins during the assembly of the head of bacteriophage T4. Nature 227: 680-685.

Luiz C., Rocha Neto A.C., Di Piero R.M. (2015) Resistance to Xanthomonas gardneri in tomato leaves induced by polysaccharides from plant or microbial origin. J. Plant Pathol. 97: 119-127.

Marmey P., Jalloul A., Alhamdia M., Assigbetse K., Cacas J., Voloudakis A., Champion A., Clerivet A., Montillet J., Nicole M. (2007) The 9-lipoxygenase GhLOX1 gene is associated with the hypersensitive reaction of cotton Gossypium hirsutum to Xanthomonas campestris pv malvacearum. Plant Physiol. Biochem. 45: 596-606.

Martinez C., Geiger J.P., Bresson E., Daniel J.F., Dai G.H., Andary C., Nicole M. (1996) Isoperoxidases are associated with resistance of cotton to Xanthomonas campestris pv. malvacearum (race 18). [in:] Plant Peroxidases: Biochemistry and Physiology. Ed. Obinger O., Burner U., Ebermann R., Penel C., Greppin H., Vienna, Austria. University of Agriculture, Switzerland, University of Geneva: 327-332.

Martinez C., Baccou J.C., Bresson E., Baissac Y., Daniel J.F., Jalloul A., Montillet J.L., Geiger J.P., Assigbetsé K., Nicole M. (2000) Salicylic acid mediated by the oxidative burst is a key molecule in local and systemic responses of cotton challenged by an avirulent race of Xanthomonas campestris pv. malvacearum. Plant Physiol. 122: 757-766.

McCue P., Shetty K. (2002) A biochemical analysis of mungbean (Vigna radiata) response to microbial polysaccharides and potential phenolic-enhancing effects for nutraceutical applications. Food Biotechnol. 16: 57-79.

Mei W., Qin Y., Song W., Li J., Zhu Y. (2009) Cotton GhPOX1 encoding plant class III peroxidase may be responsible for the high level of reactive oxygen species production that is related to cotton fiber elongation. J. Genet. Genome. 36(3): 141-150.

Meloni D., Oliva M., Martinez C., Cambraia J. (2003) Photosynthesis and activity of superoxide dismutase, peroxidase and glutathione reductase in cotton under salt stress. Environ. Exp. Bot. 49: 69-76.

Milling A., Babujee L., Allen C. (2011) Ralstonia solanacearum extracellular polysaccharide is a specific elicitor of defense responses in wilt-resistant tomato plants. PLoS one. 6: e15853.

Nwodo U.U., Green E., Okoh A.I. (2012) Bacterial exopolysaccharides: functionality and prospects. Int. J. Mol. Sci. 13(11): 14002-14015.

Orsod M., Joseph M., Huyop F. (2012) Characterization of exopolysaccharides produced by Bacillus cereus and Brachybacterium sp. isolated from Asian sea bass (Lates calcarifer). Malays. J. Microbiol. 8(3): 170-174.

Pozo M., Azcon-Aguilar C. (2007) Unraveling mycorrhiza-induced resistance. Curr. Opin. Plant Biol. 10: 393-398.

Rutherford S., Bassler B. (2012) Bacterial quorum sensing: its role in virulence and possibilities for its control. Cold Spring Harb. Perspect. Med. 2(11): a012427.

Voloudakis A., Marmey Ph., Delannoy E., Jalloul A., Martinez Ch., Nicole M. (2006) Molecular cloning and characterization of Gossypium hirsutum superoxide dismutase genes during cotton-Xanthomonas campestris pv. malvacearum interaction. Physiol. Mol. Plant Pathol. 68: 119-127.

Yun M., Torres P., El Oirdi M., Rigano L., Gonzalez-Lamothe R., Marano M., Castagnaro A., Dankert M., Bouarab K., Vojnov A. (2006) Xanthan induces plant susceptibility by suppressing callose deposition. Plant Physiol. 141: 178-187.

Zhang J., Zhou J.M. (2010) Plant immunity triggered by microbial molecular signatures. Mol. Plant. 5: 783-793. 